\title{
A Model of the Dynamics of the Effect of World Crude Oil Price and World Rice Price on Indonesia's Inflation Rate
}

\author{
P. Adam ${ }^{1,3}$, U. Rianse ${ }^{2}$, L. M. Harafah ${ }^{3}$, E. Cahyono ${ }^{1}$, M. Rafiy ${ }^{3}$ \\ ${ }^{1}$ Department of Mathematics, Universitas Halu Oleo, Kendari, Indonesia \\ ${ }^{2}$ Department of Scio-Economics of Agriculture, Universitas Halu Oleo, Kendari, Indonesia \\ ${ }^{3}$ Department of Economics, Universitas Halu Oleo, Kendari, Indonesia
}

\begin{abstract}
This study aims to investigate the dynamics of the effects of world crude oil prices and world rice prices on Indonesia's inflation rate in the period between January 2004 and September 2015. Monthly time series data spanning from January 2004 to September 2015 are analyzed using difference equation model as the econometric tool. Test result shows that there existed a dynamic effect of world oil crude prices and world rice prices on inflation rate in Indonesia. The World crude oil prices positively affected the inflation rate in that each $1 \%$ increase (decrease) in the world crude oil prices caused the inflation rate to go up (drop) by $0.33 \%$. The world rice prices also positively affected the inflation rate, where each $1 \%$ increase (decrease) in world rice prices was followed by a $0.52 \%$ rise (fall) of the inflation rate.
\end{abstract}

\section{Keywords}

Crude oil prices, rice prices, inflation rate, difference equation model.

Adam, P., Rianse, U., Harafah, L. M., Cahyono, E. and Rafiy, M. (2016) "A Model of the Dynamics of the Effect of World Crude Oil Price and World Rice Price on Indonesia's Inflation Rate", AGRIS on-line Papers in Economics and Informatics, Vol. 8, No. 1, pp. 3 - 12. ISSN 1804-1930. DOI: $10.7160 /$ aol.2016.080101.

\section{Introduction}

Crude oil has become an important commodity in the economy, and has become a commodity in world trade. Almost all countries are involved in this trade because oil is vitally needed for production inputs, transportation, and electric energy. Thus, all countries need this commodity. To fulfill their domestic needs for oil, non-oil-producing countries have to import this source of energy from other countries. Similarly, some countries that produce oil but suffer from shortage in oil supply must also import oil to meet domestic needs for this commodity. Agricultural commodities also provide inputs for production in food industries. For example, rice can be manufactured into confectionery, breakfast cereals, wafer, biscuit, and others. Increased demand for oil and agricultural commodities can therefore lead to a rise of the prices of oil and the prices of agricultural commodities.

A rise in the prices of oil and agricultural commodities can increase the prices of industrial goods, and it can even push up inflation. The impact of oil prices and agricultural commodities prices on inflation can occur either directly or indirectly. Higher oil prices have an indirect effect on inflation, while agricultural commodity prices can affect inflation directly since most of agricultural commodities can be directly consumed (Jongwanich and Park, 2011). Because oil is a raw material in industries, an increase in oil price can force companies to rise their production cost, which then cause the companies to increase the prices of their production goods. Therefore, a shock in oil price can trigger inflation, which can then lead to an economic recession (Blanc and Cinn, 2004). Agricultural industries produce food by processing it from agricultural commodities. Food is also part of consumable material group. For these reasons, an increase in the prices of agricultural commodities can increase the prices of food that are produced by industries, and this in turn can affect domestic inflation (Jongwanich and Park, 2011).

There has been a growing interest among researchers in the shock of oil prices, particularly since 1970 (Alom et al., 2013). A number of studies have investigated the effects of oil and food prices on inflation, albeit they only 
highlighted the influence of crude oil prices on inflation and other macroeconomic indicators. Among these researchers are Darby (1982), Halmilton(1983), Hunt et al. (2002), Tang and Zhang (2010), Du at al. (2010), Ahmed and Wadud (2011), Ju et al. (2014), Yalsin et al. (2014), and Katircioglu et al. (2015). Furthermore, some studies on the effects of food on inflation have been conducted by, among others, Khan and Ahmed (2014) and Belke and Awad (2015). These studies, however, did not come up with similar conclusions regarding the effect of oil prices on inflation. Ju et al. (2014), for example, reported a positive relationship between oil prices and inflation. Others, such as Ahmed and Wadud (2011), found a negative association. Some, such as Iwayemi and Fowowe (2011) and Roeger (2005), even discovered no association between oil prices and inflation. These varied findings seem to be attributable to differences in the economic conditions of the countries under investigation, in particular with regard to their dependence on oil (Sek et al., 2015). Another possible cause is the different periods which the studies looked into. Studies on the effect of oil prices on inflation were mostly focused on developed countries, for example Blanc and Chinn (2004) in the US, and only very few have been conducted to investigate the issue in developing countries. Additionally, the effects of agricultural commodity prices on inflation are still under-researched. Among few researchers who studied this area is Cheung et al. (2008).

Indonesia is one of developing countries that has oil refinery facilities to produce crude oil. Despite this fact, however, since 2003 Indonesia has become an oil-importing country (net-importer) (Wang et al., 2013). Some countries that have become the main oil suppliers to Indonesia are, among others, Saudi Arabia, Azerbaijan (Europe), Australia, Singapore (Asia), and Nigeria (Africa). Meanwhile, Indonesia is also a rice-producing country. However, the country's rice production cannot yet meet domestic demand for this commodity, and as a result it has to import rice from other countries, such as Thailand, Vietnam, and the USA. It is a fact that imports of world crude oil and world rice commodities can affect the prices of domestic food produced by industries. If this is associated with three indicators of economic trends (i.e. the prices of oil, the price of rice, and inflation), then the prices of oil, the prices of rice, and inflation indicated a similar trend during the 2004-2015 period. Brent crude oil price, for example, increased from $\$ 31.28 /$ barrel in January
2004 to $\$ 47.62 /$ barrel in September 2015. World rice price rose from $\$ 8.06$ per hundredweight in January 2004 to $\$ 13.2$ per hundredweight in September 2015. Meanwhile, in the same period Indonesia's inflation rate rose from $4.82 \%$ in January 2004 to $6.83 \%$ in September 2015.

This study aims to examine the dynamics of the effects of world crude oil prices and world rice prices on Indonesia's inflation rate in the period from January 2004 to September 2015. An econometric model used to analyze the effect of crude oil price and the world rice price is the difference equation model proposed by Enders (2015). This model is selected based on an assumption that a certain time lag is required for the prices of world crude oil and world rice to affect inflation. Test results are then expressed in a model of mathematical equation, i.e. the difference equations. Based on this model, a curve diagram called a signal process is created to illustrate the dynamics of the effect of world oil prices and world rice prices on inflation, as has been performed by Cahyono (2014), Adam et al. (2014), and Adam (2014).

\section{Review of literature}

In theory, the effects of world crude oil prices and agricultural commodities prices (including rice) on inflation rate can occur through the following channels. Crude oil and agricultural commodities are industrial raw materials. A rise in crude oil prices can increase transportation costs, as well as cost of inputs, such as fertilizer, which in turn can push up the prices of agricultural commodities (Kapusuzoglu and Ulusoy, 2015; Adam, 2015). Furthermore, the prices of crude oil and agricultural commodities can raise production cost of non-food and food industries. An increase in production costs can raise the prices of goods, and at the same time it can reduce company's production, decreasing outputs and in turn leading to inflation (Alom et al., 2013). In terms of trade, increased prices of oil and agricultural commodities can raise the prices of industrial goods in importing countries (Johnwanich and Park, 2009; Misati et al., 2013). Therefore, an increase in the prices of world crude oil and agricultural commodities can cause inflation worldwide (Alom et al., 2013)

Rice is a staple food in some countries, such as Indonesia and Nigeria, and therefore it is consumed more by households in these countries. For this reason, agricultural commodities, especially rice, are imported not only to meet the needs of food 
industries, but also to fulfill households' growing demand for the food. Increasing demand for food commodities (including rice) at a rate that is higher than an increasing rate of production can cause the price of this commodity to escalate and can in turn affect inflation (Sasmal, 2015). Apparently, however, an increase in rice price cannot keep people from buying rice to meet their basic need for food. Therefore, if rice prices go up, household consumption is also increased, and this means that, as reported by Oynbo et al. (2013), rice price is positively correlated with household spends for consumption.

Empirically, some studies investigating the effect of oil prices and prices of agricultural commodities and food industry on inflation have been conducted in many countries. Blanc and Chinn (2004) examined the effect of oil prices on inflation in the USA, Japan, and Europe. Their results showed that a $10 \%$ increase in oil prices affected inflation by about 0.1 to $0.8 \%$. They also found that the response of inflation toward oil prices was more sensitive in Europe than it was in the US. Alvares et al. (2011) conducted a study in several countries (i.e. Spain, the Euro Area, Germany, France), and found that fluctuation in the price of oil was a cause of inflation, and that the impact of oil prices on inflation in Spain was higher than it was in the Euro Area. Lu et al. (2010) examined the transmission of volatility between oil shocks and inflation in Taiwan in the period from January 1986 to December 2008. They discovered that the price of oil had a nonlinear effect on inflation. Meanwhile, a volatility in oil prices had a very strong influence on inflation. Sek et al. (2015) conducted a study on the effect of oil prices on inflation. They split the study sites into two groups, namely a group of countries with a very high dependence on oil (Singapore, South Korea, Philippines, Greece, Belgium, Italy, Pakistan, India, Portugal, Spain), and a group of countries with low dependence on oil (Norway, Denmark, United Kingdom, Canada, Mexico, Malaysia, Brazil, Venezuela, Ecuador, Bulgaria). Their results showed that oil prices significantly affected domestic inflation. The influence of oil prices in the countries with a high dependence on oil was indirect, meaning that the effect of oil prices occurred through changes in export production costs, whereas a direct effect of oil prices on inflation occurred in the countries with low dependence on oil.

Not only do oil prices affect inflation, but also other macroeconomic indicators. Therefore, a lot of researchers have studied the effect of oil prices on inflation and other macroeconomic variables. Cunado and Gracia (2003), for instance, investigated the relationship between oil prices and two macroeconomic variables, i.e. inflation and output, in some European countries in the period of 1960-1999. Result showed that there was a permanent effect of oil prices on inflation in the short term, and there was the asymmetric effect of oil prices on production index. Cunado and Gracia (2005) did a research in Asian countries (Japan, Malaysia, Thailand, Singapore, South Korea, and the Philippines) within the 1975Q1 -2002 Q2 period. In their study, a dummy variable was used to determine the change in the structure of the effect of world oil prices on domestic oil prices, exchange rates, and inflation. Results of analysis indicated that while in the long term oil price affected inflation, the short-term effect of oil prices on inflation was limited. Yalcin et al. (2015) examined the influence of unanticipated oil price changes on three macroeconomic indicators including inflation (CPI), real exchange rate (RER), and GDP, in Turkey. Based on their data analysis, they found that when oil price increases, CPI and RER increases but GDP decreases in the long term.

Cheung et al. (2008) looked into the effects of food commodity prices on inflation in several Asian countries in the 1962-2003 period. Results of analysis using the Philips Curve showed that food prices affected inflation. Ratnasari (2009) investigated factors affecting inflation in Sri Lanka in the period of 1980-2005, and reported that two main factors contributing to inflation were growing supply of money and increased prices of rice. Myint and Bauer (2010) examined markets integration and causal relationship between the prices of local rice and international rice (Thai rice), as well as the effect of the prices on consumer price index in Myanmar from 2001 to 2004. Monthly data were analyzed using the VAR analysis. Test results showed that while market integration was weakened in domestic market, a deficit in the prices of rice affected the consumer price index. Abdoulaye et al. (2015) examined the effect of the prices of cereal commodities (rice, corn, and wheat) on inflation (which was proxied with the consumer price index) in Mali from 1993 to 2015. Results indicated that there was an effect of cereal prices on inflation in Mali in the long term, and there was none in the short term. Belke and Awad (2015) examined the effect of food prices on inflation in MENA, and reported that there were some long-term effects of the prices of food commodity on inflation. 
Misati et al (2013) examined the effect of food prices and oil prices on inflation in Kenya. Results of VAR analysis indicated that the prices of oil and food commodity served an important role in measuring inflation. Alom et al. (2013) investigated the effect of oil prices and the prices of agriculture commodities on several macroeconomic indicators (i.e. inflation, lending rate, exchange rate, index of production, and the stock price index) in some Asian-Pacific countries (Korea, Thailand, Singapore, India, Hong Kong, Australia, and New Zealand) in the 1980Q1 -2010Q2 period. Results of analysis using SVAR showed that oil prices affected all macroeconomic variables in all of the countries under investigation, except in Singapore and Hong Kong. The prices of food commodities had a positive effect on inflation, and this occurred only in Korea and Thailand. Khan and Ahmed (2014) studied the effect of oil prices and food commodity prices on Pakistan's economy from January 1990 to July 2011. Results of SVAR analysis showed that while a shock in oil prices negatively affected production index and exchange rate, it had a positive effect on inflation. Further revealed was a fact that the prices of food commodities had a positive effect on inflation.

\section{Material and methods}

\section{Data}

This study analyzed three types of data, i.e. the prices of world crude oil, the prices of world rice, and Indonesian's inflation rate. The prices of world crude oil are referred to European crude oil price (Brent Spot Price) (USD per barrel), whereas world rice prices are referred to the prices of rough rice (USD per hundredweight). Brent crude oil price is chosen based on a consideration that its prices of crude oil have become one of the references for the prices of crude oil in world crude oil market, while the prices of rough rice has become an imported commodity in Indonesia. Data about the prices of crude oil is taken from the International Energy Administration (www.tonto.eia.gov), while the data about the prices of world rice prices is obtained from the Fusion Media Limited (http://uk.investing.com/commodities). Data about Indonesia's inflation rate (\%) is retrieved from Bank of Indonesia (www.bi.go.id). The three types of data are time series monthly data which spanned from January 2004 to September 2015.

The time-series data of world crude oil prices, world rice price, and inflation rate are taken from three websites and are expressed respectively by $O I L_{t}^{o}, R I C_{t}^{0}$, and $I N F_{t}^{0}$ in which $t$ is time (in month). For the purpose of analysis, the $O I L, R I C$, and INF variables are used with $O I L=\log \left(O I L^{0}\right), \quad R I C=\log \left(R I C^{0}\right)$, and $I N F=\log \left(I N F^{0}\right)$.

\section{Method of analysis}

The prices of both world crude oil and world rice require a certain time lag to induce any effect on inflation rate. In the meantime, Indonesian government has always made every efforts to control the inflation rate by applying monetary policy, therefore current inflation rate can be associated with inflation rate in the past. Based on this assumption, an econometric model that is used to test the effects of world crude oil prices and world rice prices on inflation rate is the difference equation model proposed by Enders (2015). The model is formulated as follows

$$
I N F_{t}=a_{0}+\sum_{i=1}^{n} a_{i} I N F_{t-i}+b O I L_{t-p}+c R I C_{t-q}+\epsilon_{t}
$$

in which $n$ is the order of difference equation with $\left|\mathrm{a}_{\mathrm{i}}\right|<1, i=1,2,3, \ldots, n$. The term of $b O I L_{t-p}$ $+c R I C_{t-q}$ is called the forcing process, $b$ and $c$ are a short-term multiplier effect. $\epsilon_{t}$ is white noise with $E\left(\varepsilon_{t i} \epsilon_{t j}\right)=0, \quad i \neq j, E\left(R I C_{t} \varepsilon_{t-i}\right)=0$, and $E\left(O I L_{t} \varepsilon_{t-i}\right)=0$, whereas $p$ and $q$ is time lag. The $I N F$, OIL, and RIC variables are needed to meet a requirement for stationarity.

Model (1) is a special case of the autoregressive distributed lag, namely the ADL model (Enders, 2015) or is a special case of lagged-variable autoregressive model, namely LVAR model (Agung, 2009; Adam, 2014). The following is the ADL model:

$$
\begin{aligned}
I N F_{t} & =a_{0}+\sum_{i=1}^{n} a_{i} I N F_{t-i}+\sum_{j=0}^{p_{0}} b_{j} O I L_{t-j} \\
& +\sum_{k=0}^{q_{0}} c_{k} R I C_{t-k}+\epsilon_{t}
\end{aligned}
$$

in which $n, p_{0}$ and $q_{0}$ is time lag. The relationship between $p_{0}$ and $q_{0}$ and $p$ and $q$ from (1) is $0 \leq p \leq p_{0}$ and $0 \leq q \leq q_{0}$. In an equilibrium condition, all variables in equation (2) fulfill $I N F_{t}=I N F_{t-1}=I N F_{t-2}=\ldots=I N F_{t-n} ; O I L_{t}=O I L_{t-1}=$ $O I L_{t-2}^{t}=\ldots \stackrel{t-1}{=} O I L_{t-p_{0}}$; and $R I C_{t}^{t-n}=R I C_{t-1}^{t}=R I C_{t-2}^{t-1}=$ $\ldots=R I C_{t-q_{0}}$, then, equation (2) becomes

$I N F_{t}=\frac{a_{o}}{1-\sum_{i=1}^{n} a_{i}}+\frac{\sum_{j=0}^{p_{0}} b_{j}}{1-\sum_{i=1}^{n} a_{i}} O I L_{t}+\frac{\sum_{k=0}^{p_{0}} c_{j}}{1-\sum_{i=1}^{n} a_{i}} R I C_{t}$

The magnitude of the long-term effect of world crude oil prices (OIL) is 
$\delta_{1}=\frac{\sum_{j=0}^{p_{0}} b_{j}}{1-\sum_{i=1}^{n} a_{i}}$

while the magnitude of the long-term effect of world rice price $(R I C)$ is

$$
\gamma_{1}=\frac{\sum_{k=0}^{p_{0}} c_{j}}{1-\sum_{i=1}^{n} a_{i}}
$$

(Heij et al., 2004). Therefore, based on (3) and (4), it can be obtained from (1) that the magnitude of the long-term effect of world crude oil price is $\delta=\frac{b}{1-\sum_{i=1}^{n} a_{i}}$, whereas the magnitude of the long term effect of world rice price is $\gamma=\frac{c}{1-\sum_{i=1}^{n} a_{i}}$.

To test the dynamics of effect of world crude oil prices and world rice prices on inflation rate, an analysis is conducted in the following steps. Firstly, the Augmented Dickey Fuller test is performed to determine the stationarity of time series $O I L, R I C$, and INF. For example, the stationary time series $O I L$ is tested by determining the significance of parameter $\rho$ in the following equation:

$$
\begin{aligned}
D\left(O I L_{t}\right) & =\alpha+\beta t+\rho O I L_{t-1} \\
& +\sum_{i=1}^{n} \theta_{i} D\left(O I L_{t-i}\right)+\varepsilon_{t}
\end{aligned}
$$

in which $D\left(O I L_{t}\right)=O I L_{t}-O I L_{t-1}$ is a form of the first difference of the world crude oil variable $(O I L)$. Hypothesis $\mathrm{H}_{0:} \rho=0$ shows that time series $O I L$ has a unit root, or in other words, time series $O I L$ is not stationary. Hypothesis $\mathrm{H}_{1}:-2<\rho<0$ shows that time series OIL is stationary (Koop, 2006). According to Widarjono (2009), the time series data of OIL is said to be stationary, if the absolute value of ADF statistics is higher than the absolute value of ADF-critics at a level of significance $\propto(1 \%$ or $5 \%$ ). Secondly, a cointegration test is run when all of the time series data are not stationary at level, but they are stationary on difference (Widarjono, 2009). The Granger Two Step Test is employed to test the cointegration of time series $O I L, R I C$, and $I N F$, through two steps. Firstly, the multiple regression equation between $O I L, R I C$, and $I N F$ is estimated. The residuals of this equation with the $R E S$ is saved, as follows

$R E S_{t}=I N F_{t}-\alpha O I L_{t}-\beta R I C_{t}$

where $\alpha$ and $\beta$ are regression parameters. Next, a test on unit root is conducted. If RES is stationary at level, then the three time series data of OIL, RIC, and $I N F$ are said to be cointegrated. In this case, the regression model is an error correction model
(ECM), as follows

$$
\begin{aligned}
& D\left(I N F_{t}\right)=a_{0}+\sum_{i=0}^{n} a_{i} D\left(I N F_{t-i}\right)+b D\left(O I L_{t-p}\right) \\
& +c D\left(R I C_{t-q}\right)+d R E S_{t-1}+\epsilon_{t}
\end{aligned}
$$

in which RES is error correction, and $d$ is parameter (Rosadi, 2012). Finally, a test on the dynamics of the effect is performed by estimating the regression parameters and examining the parameter significance. A statistical test that is used to estimate the parameter regression is the F-statistics test on all parameters, or the t-statistics test on individual parameter by using the level of significance $\alpha$ ( $1 \%$ or $5 \%$ ). Additionally, P-value criteria is used in testing the significance of the regression parameters.

A good model of regression is one with significant explanatory variables. Good models in (1) and (2) are related to the selection of lag length. There is no general convention about how to select the length of lag. One way to do this is by estimating the regression model (2) in such a way that $a_{i}, b_{j}$, and $c_{k}$ coefficient are significant at a maximum length of lag (Koop, 2006). Estimating the parameter can be done repeatedly using a backward method, discarding variables with insignificant coefficient (Rosadi, 2012). Other way is by firstly determining the length of lag $n$ in such a way that $a_{i}$ is significant. Then, $p_{0}$ and $q_{0}$ are determined in such a way that $b_{j}$ and $c_{k}$ are significant, and the value of Akaike Information Criterion (AIC) is minimum (Hill et al., 2011).

Given that model (1) is a special of ADL (Enders, 2015), the first thing we do is estimating regression equation (2), followed by selecting explanatory variables with significant coefficient. Next, we re-estimate to obtain model (1). To come up with the best model of estimation, we use AIC as information criteria in setting the time lag $n, p$ and $q$. We also compare the statistical value of R-squared $\left(\mathrm{R}^{2}\right)$ to the statistical values of Durbin Watson $(D W)$ to make sure that the regression model is not spurious. According to Rosadi (2012), a regression model is not a spurious one if the statistical value of $D W$ is greater than the statistical value of $\mathrm{R}^{2}$.

\section{Results and discussion}

\section{Unit root test}

Results of estimation with regard to the stationary test are summarized in Table 1. As shown in the table, the three time series data of world crude oil prices $(O I L)$, world rice prices $(R I C)$ and inflation rate $(I N F)$ are not stationary at the level 


\begin{tabular}{|l|c|c|c|c|}
\hline Variable & ADF-Statistics & $1 \%$ Critical Value & $5 \%$ Critical Value & Prob. $^{*}$ \\
\hline$I N F$ & -2.897638 & -3.477835 & -2.882279 & 0.0482 \\
\hline$D(I N F)$ & -5.554477 & -3.482035 & -2.884109 & 0.0000 \\
\hline$O I L$ & -2.676216 & -3.477835 & -2.882279 & 0.0807 \\
\hline$D(O I L)$ & -8.617120 & -3.477835 & -2.882279 & 0.0000 \\
\hline$R I C$ & -2.000854 & -3.477487 & -2.882127 & 0.2863 \\
\hline$D(R I C)$ & -13.15527 & -3.477835 & -2.882279 & 0.0000 \\
\hline
\end{tabular}

* MacKinnon (1996) one-sided p-values

Source: own processing

Table 1: Estimation result of stationary test.

\begin{tabular}{|l|c|c|c|c|}
\hline Variable & ADF-Statistics & $1 \%$ Critical Value & $5 \%$ Critical Value & Prob.* $^{*}$ \\
\hline$R E S$ & -2.801489 & -3.482035 & -2.884109 & 0.0609 \\
\hline
\end{tabular}

* MacKinnon (1996) one-sided p-values

Source: own processing

Table 2: Estimation results of cointegration test.

\begin{tabular}{|l|c|c|c|c|c|}
\hline Variables & Coefficient & Std. Error & t-Statistic & Prob. & Other Statistics \\
\hline$D($ INFt- $)$ & 0.404107 & 0.088261 & 4.578538 & 0.0000 & $\mathrm{R}^{2}: 0.252786$ \\
\hline$D($ INFt-2 $)$ & -0.217390 & 0.087817 & -2.475500 & 0.0148 & $\mathrm{DW}: 2.027745$ \\
\hline$D($ OILt-7) & 0.266558 & 0.129669 & 2.055679 & 0.0422 & AIC: -1.287498 \\
\hline$D($ RICt-27) & 0.427076 & 0.132586 & 3.221133 & 0.0017 & \\
\hline
\end{tabular}

Source: own processing

Table 3: Estimation results of testing the dynamics of the effect.

of significance $1 \%$, since all of the absolute values of ADF-statistics are lower than those of the ADFcritics. The prices of world crude oil, the prices of world rice, and the inflation rate are stationary at the first difference or are integrated order one, $I(1)$.

\section{Cointegration test}

In running the cointegration test, time series data of RES is first constructed using (5). Table 2 presents a summary of the estimation results of ADF-statistics and the ADF-critics. By comparing the value of ADF-statistics with the value of ADF-critics, RES is not integrated of order zero, $\mathrm{I}(0)$. Therefore, the prices of world crude oil, the prices of world rice, and the inflation rate are not cointegrated.

\section{Dynamics of the effect}

Since, the prices of world crude oil, the prices of world rice, and the inflation rate are not cointegrated, the regression parameters being estimated are those of model (1). All the statistical values of the estimation results are summarized in Table 3.

As is indicated in Table 3, the coefficient of $O I L_{t-7}$ is significant by $5 \%$, whereas the coefficient of $R I C_{t-27}$ is significant by $1 \%$. This means that simultaneously, there was a dynamic of the effect of world crude oil prices and world rice price on inflation rate. This finding confirms the results reported by Misati et al. (2013), Alom et al. (2013), and Kant and Ahmed (2014), which stated that simultaneously the prices of world crude oil and world rice prices affected the rate of inflation, although these researchers conducted their studies in different settings and periods. Inflation rate is also influecned by past rate of inflation, namely $\mathrm{D}\left(I N F_{t-1}\right)$, and $\mathrm{D}\left(I N F_{t-2}\right)$. The effect exerted by past inflation rate, prices of world crude oil, and world rice prices on current inflation rate $\mathrm{D}\left(I N F_{\mathrm{t}}\right)$ is $\mathrm{R}^{2} \times 100 \%=25.2786 \%$. Thus, other factors contribute the remaining $74.7214 \%$ to the current rate of inflation. This needs further research.

Partially, there was an effect of world crude oil prices on inflation rate. The prices of world crude oil required a time lag of seven months to affect the inflation rate. The dynamics of the effect of the world crude oil price on inflation rate is positive with long term multiplier effect $\delta=0.33$. Given this multiplier effect, every $1 \%$ increase 


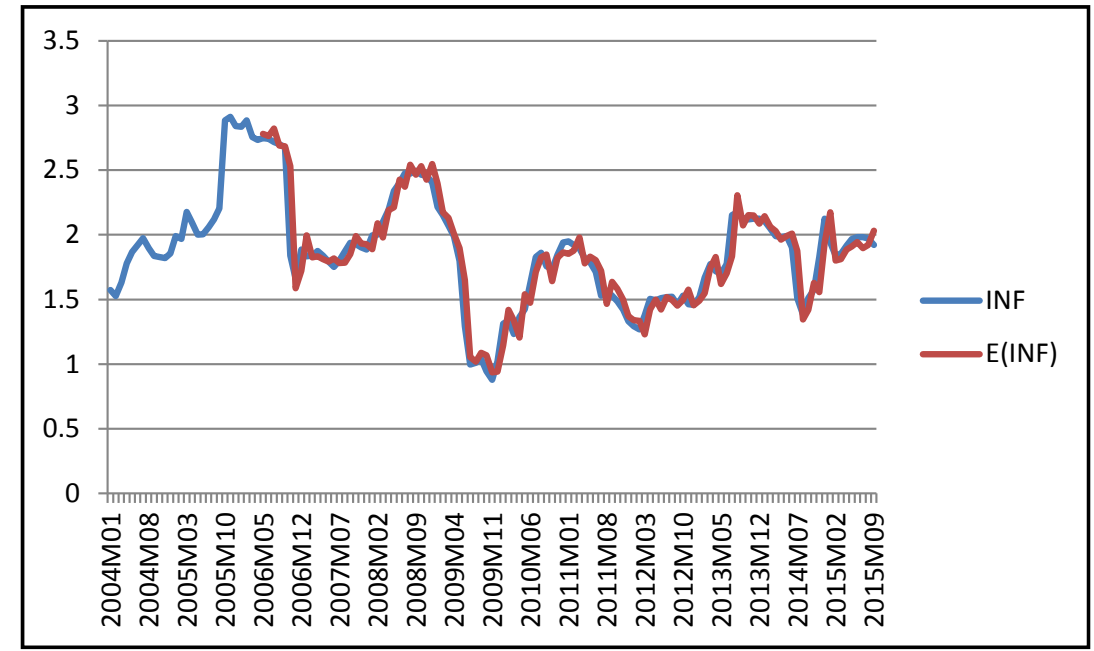

Source: own processing

Figure 1: A signal of the dynamic effects of world crude oil prices and world rice prices on the inflation rate based on the equation (8).

(decrease) in the world crude oil prices rose (fell) inflation rate by $0.33 \%$. Likewise, every $1 \%$ decrease (increase) in the world crude oil prices caused the inflation rate to drop (go up) by $0.33 \%$. The results of this analysis is consistent with what was reported by Blanc and Cinn (2004), Alvares et al. (2011), Lu et al. (2013), Sek et al. (2015), Gunado and Gracia (2003), Cunado and Gracia (2005), Ju (2014), and Yalcin et al.(2015). However, except Blanc and Cinn (2004), these researchers did not report the contribution of world crude oil prices on inflation. Furthermore, this particular finding of current research is different from the results of research conducted by Ahmed and Wadud (2011). The difference may be attributed to the economic condition of the countries in the period under investigation (Sek et al., 2015).

The price of world rice also affected the inflation rate positively with long term multiplier effect $\gamma=0.52$. The prices of world rice required a time lag of twenty-five months to affect the inflation rate. Given the multiplier effect, each $1 \%$ increase in the price of world rice caused a $0.52 \%$ increase in inflation rate. The finding of this study is similar to the results reported by Cheung et al. (2008), Ratnasari (2009), Myint and Bauer (2010), Abdoulaye et al. (2015), and Belke and Awad (2015), although these researchers did not indicate the extent to which the prices of food commodities affected inflation rate.

Based on the estimation result of the regression parameters, the following model of difference equation is then developed:

$$
\begin{aligned}
\mathrm{D}\left(I N F_{t}\right) & =0.404107 \mathrm{D}\left(I N F_{t-1}\right)-0.21739 \mathrm{D}\left(\operatorname{INF}_{t-2}\right) \\
& +0.266558 \mathrm{D}\left(O I L_{t-7}\right)+0,427076 \mathrm{D}\left(R C_{t-22}\right)
\end{aligned}
$$

Because $\mathrm{D}\left(I N F_{t}\right)=I N F_{t}-I N F_{t-1}$, then the value of forecasting the inflation rate $\mathrm{E}(\mathrm{INF})$ as a result of the effects of world crude oil prices and world rice prices in the period January from 2004 to September 2015 is determined by the following equation

$$
\begin{aligned}
\mathrm{E}\left(I N F_{t}\right) & =I N F_{t-1}+0.40407 \mathrm{D}\left(I N F_{t-1}\right) \\
& -0.21739 \mathrm{D}\left(I N F_{t-2}\right) \\
& +0.266558 \mathrm{D}\left(\text { OIL }_{t-7}\right) 0.427076 \mathrm{D}\left(R I C_{t-27}\right)
\end{aligned}
$$

As noted earlier, the prices of world crude oil and world rice required a certain time lag to influence the inflation rate in period 2004:01-2015:09. In a signal process, the information of the delay is shown in Figure 1. The red curve (curve of $\mathrm{E}(I N F)$ ), which almost coincides with the blue curve (curve of $I N F$ ), indicates the dynamics of the effects of world crude oil prices and the world rice prices on the inflation rate.

\section{Conclusion}

This study aims to investigate the effects of world crude oil prices and the prices of world rice on Indonesia's inflation rate in the period from 2004:01 to 2015: 09. For this purpose, monthly data are analyzed. An econometric tool used to test this effect is the difference equation model, which is a special form of the Autoregressive Distributed Lag model. 
Results of statistical test indicated that the prices of world crude oil, the price of world rices, and the inflation rate are integrated order one, $I(1)$. The three time series data are not cointegrated. Test results indicate that there was a dynamic effect of the world crude oil prices and the world rice prices on inflation rate. The prices of world crude oil positively affected the inflation rate, in which each $1 \%$ increase (decrease) in world crude oil prices was followed by $0.33 \%$ increase(decrease) in the inflation rate. Similarly, the prices of world rice positively affected the inflation rate, in which each $1 \%$ increase(decrease) in world rice prices caused the inflation rate to rise (fall) by $0.52 \%$.

Corresponding author:

Pasrun Adam

Department of Mathematics, Universitas Halu Oleo, Kampus Bumi Tridharma, Kendari 93232, Indonesia Phone :+62811401251, Email: adampasrun@gmail.com

\section{References}

[1] Abdoulaye, C., Hui, W. L. and Beckline, M. (2015) "Assessing the Impact of Cereal Prices on Consumer Price Index in Mali", Journal of Finance and Economics, Vol. 3, No. 6, pp 112-121. ISSN 2328-7284, E-ISSN 2328-7276.

[2] Agung, I. G. N. (2009) "Time series data analysis using Eviews", 2009, Singapore: Wiley \& Son Inc. ISBN 978-0-470-82367-5.

[3] Ahmed, H. J. A. and Wadud, I. K. M. M. (2011) "Role of oil price shocks on macroeconomic activities: An SVAR approach to the Malaysian economy and monetary responses", Energy Policy. Vol. 39, pp. 8062-8069. ISSN 0301-4215.

[4] Adam, P., Gubu, L., Cahyono, E. (2014) "Statistical characteristics of Jakarta Composite Index (JCI) dynamics based on short term data represented in candles", International Journal of Economics Finance and Management Sciences, Vol. 2, No. 2, pp. 138-142. ISSN 2326-9553, E-ISSN 2326-9561.

[5] Adam, P. (2014) "Model dinamika hubungan antara harga minyak mentah dunia, neraca perdagangan, kurs dollar US, dan Indeks Harga Saham Gabungan". Dissertation of a doctoral program at the Economic Studies Program, Graduate Program, UHO (unpublished).

[6] Adam, P. (2015) "A model of the dynamics of the relationship between the prices of world crude oil and the prices of rice". Proceeding of the celebes international conference on divercity at Wallacea's Line (CICWDL), pp. 453-458. ISBN 978-602-8161-81-7.

[7] Alom, F., Ward, B. D. and Hu, B. (2013) "Macroeconomic effects of world oil and food price shocks in Asia and Pasific economies: application of SVAR models", Opec Energy Review. September 2013, Vol. 37, No. 3, pp. 327-372. ISSN 1753-0237.

[8] Alvares. L. J., Hurtado, S., Sanchez, I., and Thomas. C. (2011) "The impact of oil price changes on Spanish and euro area consumer price inflation", Economic Modelling, Vol. 28, pp. 422-431. ISSN 0264-9993.

[9] Belke, A. and Awad, J. (2015) "On the pass-through of food prices to local inflation in Mena Countries". WSEAS Transactions on Business and Economics, Vol.12, pp. 307-316. ISSN 1109-9526, E-ISSN 2224-2899.

[10] Blanc, M, L. and Chinn, M. D. (2004) "Do High Oil Prices Presage Inflation? The Evidence from G-5 Countries". Social Science Research Network. February 2004, pp. 1-25. [Online] SSRN: http://dx.doi.org/10.2139/ssrn.509262 [Accessed: Jan 15, 2015]

[11] Cahyono, E. (2014) "On the linear relation of signals". WSEAS Transactions on Signal Processing. Vol. 10, pp. 555-560. ISSN 1790-5052, E-ISSN 2224-3488.

[12] Cheung, L., Szeto, J., Tam, C.-S. and Chan, S. (2008) "Rising food prices in Asia and implications for monetary policy", Hong Kong Monetary Authority Quarterly Bulletin. September 2008, p. 1-10, ISSN 1726-9741. 
[13] Cunado, J. and Gracia, D. F. P. (2003) "Do oil price shocks matter? Evidence for some European countries", Energy Economics. Vol. 25, pp. 137-154. ISSN 0140-9883.

[14] Cunado, J. and Gracia, D. F. P. (2005) "Oil prices, economic activity and inflation: evidence for some Asian countries", The Quarterly Review of Economics and Finance, Vol. 45, pp. 65-83. ISSN 1062-9769.

[15] Darby, M. R. (1982) "The price of oil and world Inflation and recession", The American Economic Review, September 1982, Vol. 72, pp. 738-751. ISSN 00028282.

[16] Du, L., He, Y., and Wei, C. (2010) "The relationship between oil price shocks and China's macro-economy: An empirical analysis", Energy Policy, Vol. 38, pp. 4142-4151. ISSN 030-215.

[17] Enders, W. (2015) Applied econometric time series (fourth edition). New York: John Wiley \& Son Inc. ISBN 978-1-118-80856-6.

[18] Hamilton, J. D. (1983) "Oil and the macroeconomic since world war II". Journal of Political Economy. Vol. 9, pp. 228-248. ISSN 0022-3808, E-ISSN 1537-534X.

[19] Heij, C., Boer, D. P., Franses, P. H., Kloek, T. and Dijk, V. H. H. (2004) Econometric methods with applications in business and economics. New York: Oxford University Press Inc. ISBN 0-19-926801-0.

[20] Hill, R. C., Griffiths, W. E. and Lim, G. (2011) Principles of econometrics (fourth edition). Danvers: John Wiley \& Son Inc. ISBN 978-0-470-62673-3.

[21] Hunt, B., Isard P. and Laxton, D. (2002) "Macroeconomic effects of higher oil prices", National Institut Economics Review, Vol. 179, pp. 87-102, ISSN 0027-9501

[22] Iwayemi, A. and Fowowe, B. (2011) "Impact of oil price shocks on selected macroeconomic variables in Nigeria", Energy Policy, Vol. 39, pp. 603-612. ISSN 030-215.

[23] Jongwanich, J. and Park, D. (2009) "Inflation in developing Asia", Journal of Asian Economics, Vol. 20, pp. 507-518, ISSN 1049-0078.

[24] Jongwanich, J. and Park. D. (2011) "Inflation in developing Asia: pass-through from global food and oil price shocks", Asian-Pasific Economic Literature, Vol. 25, No. 1, pp. 79-85. ISSN 1467-8411.

[25] Ju, J., Zhou, D., Zhou, P. and Wu, J. (2014) "Macroeconomic effects of oil price shocks in China: An empirical study based on Hilbert-Huang transform and event study", Applied Energy, Vol. 136, No. 12, pp. 1053-1066. ISSN 0306-2619.

[26] Kapuzoglu, A. and Ulusoy, M. K. (2015) "The interactions between agricultural commodity and oil prices: an empirical analysis", Agricultural Economics (AGRICECON), Vol. 61, No. 9, pp. 410-421, ISSN 0139-570X, E-ISSN 1805-9295.

[27] Katircioglu, S. T., Sertoglu, K., Candemir, M. and Mercan, M. (2015) "Oil price movements and macroeconomic performance: Evidence from twenty-six OECD countries", Renewable and Sustainable Energy Reviews, April 2015, Vol. 44, pp. 257-270. ISSN 1364-0321.

[28] Khan, M. A. and Ahmed, A. (2014) "Revisiting the macroeconomic effects of oil and food price shocks to Pakistan economy: a structural vector autoregressive (SVAR) analysis", OPEC Energy Review, Vol. 38, No. 2, pp. 184-215. ISSN 1753-0237.

[29] Koop, G. (2006) Analysis of financial data, London: Wiley \& Son Inc. ISBN 13 978-0-470-01321-2.

[30] Lu, W.-C., Liu, T.-K. and Tseng, C.-Y. (2010) "Volatility transmissions between shocks to the oil price and inflation: evidence from a bivariate GARCH approach". Journal of Information and Optimization Sciences, Vol. 31, No. 4., pp. 927-939. ISSN 0252-2667.

[31] Misati, R. N., Nyamongo, E. M. and Mwangi, I. (2013) "Commodity price shocks and inflation in a net oil-importing economy", OPEC Energy Review. Vol. 37, No. 2, pp. 125-148. ISSN 1753-0237. 
[32] Myint, T. and Bauer, S. (2010) "Market Integration and Price Causality in the Myanmar Rice Market", Asian Journal of Agriculture and Development, Vol. 7, No. 2, pp. 91-105. ISSN 1656-4383.

[33] Oyinbo, O., Omolehin., R. A. and Salam, A. Z. (2013) "Analysis of the demand for rice in Kanduna State, Nigeria", Agris on-line Papers in Economics and Informatics, Vol. 5, No. 3, pp. 45-52. ISSN 1804-1930

[34] Ratnasiri, H. P. G. S. (2009) "The Main Determinants of Inflation in Sri Lanka: A VAR based Analysis", Staff Studies, Vol. 39, No 1-2, pp. 1-14. ISSN 1391-3743.

[35] Roeger, W. (2005) "International oil price changes: impact of oil prices on growth and inflation in the EU/OECD", International Economics and Economic Policy, Vol. 2, No. 1, pp. 15-32. ISSN 1612-4804, E-ISSN 1612-4812.

[36] Rosadi, D. (2012) Ekonometrika \& analisis Runtun waktu terapan dengan EViews aplikasi untuk bidang ekonomi, bisnis, dan keuangan. Jogyakarta: C.V Andi Offset. ISBN 978-979-29-3041-2.

[37] Sasmal, J. (2015) "Food price inflation in India: the growing economy withsluggish agriculture", Journal of Economics, Finance and Administrative Science. Vol. 20, No. 38, pp. 30-40. ISSN 2077-1886

[38] Sek, S. K., Teo, X. Q. and Wong, Y. N. (2015) "A Comparative Study on the Effects of Oil Price Changes on Inflation", Procedia Economics and Finance. Vol. 26, p. 630 - 636. ISSN 2212-5671.

[39] Tang, W., Wu, L. and Zhang, Z. X. (2010) "Oil price shocks and their short- and long-term effects on the Chinese economy", Energy Economics, Vol. 32, p. S3-S14. ISSN 0140-9883.

[40] Wang, Y., Wu, C., Yang, L. (2013) "Oil price shocks and stock market activities: evidence from oil-importing and oil-exporting countries", Journal of Comparative Economics, November 2013, Vol. 41, No. 4, pp. 1220-1238. ISSN 0147-5967.

[41] Widarjono, A. (2009) Ekonometrika pengantar dan aplikasinya. Jogyakarta: Penerbit Ekonisia. ISBN 978-979-9015-55-2.

[42] Yalcin, Y., Arikan, C. and Emirmahmutoglu, F. (2015) "Determining the asymmetric effects of oil price changes on macroeconomic variables: a case study of Turkey", Empirica, Vol. 42, No. 4, pp. 737-746. ISSN 0340-8744, E-ISSN 1573-6911. 